\title{
Kidney Cancer Pathologic Regional Lymph Nodes TNM Finding v6
}

National Cancer Institute

\section{Source}

National Cancer Institute. Kidney Cancer Pathologic Regional Lymph Nodes TNM Finding v6. NCl Thesaurus. Code C63558.

A pathologic finding about one or more characteristics of kidney cancer, following the rules of the TNM AJCC V6 classification system as they pertain to staging of regional lymph nodes. Laterality does not affect the $\mathrm{N}$ classification. 